\title{
Impurity effects on phase and microstructure stabilities of reactively-sintered porous $\mathrm{MgTi}_{2} \mathrm{O}_{5}$
}

\author{
Xinzhu MIAO a, Yoshikazu SUZUKI a,b* \\ ${ }^{a}$ Graduate School of Pure and Applied Sciences, University of Tsukuba, 1-1-1 Tennodai, \\ Tsukuba, Ibaraki 305-8573, Japan \\ ${ }^{\mathrm{b}}$ Faculty of Pure and Applied Sciences, University of Tsukuba, 1-1-1 Tennodai, Tsukuba, \\ Ibaraki 305-8573, Japan
}

\begin{abstract}
:
Since the thermal-expansion anisotropy of pseudobrookite-type $\mathrm{MgTi}_{2} \mathrm{O}_{5}$ is not as prominent as isomorphic $\mathrm{Al}_{2} \mathrm{TiO}_{5}, \mathrm{MgTi}_{2} \mathrm{O}_{5}$ is thermally more stable than $\mathrm{Al}_{2} \mathrm{TiO}_{5}$. To realize the future structural applications of porous $\mathrm{MgTi}_{2} \mathrm{O}_{5}$, influence of impurities on the phase and microstructure stabilities should be studied. Here, impurity effects on phase and microstructure stabilities of reactively-sintered porous $\mathrm{MgTi}_{2} \mathrm{O}_{5}$ have been studied. As model impurities, $\mathrm{Li}_{2} \mathrm{CO}_{3}$ and amorphous $\mathrm{SiO}_{2}$ have been selected. $\mathrm{Li}_{2} \mathrm{CO}_{3}$ or $\mathrm{SiO}_{2}$ powder (0.1-4.0 wt.\%) was added to $\mathrm{MgCO}_{3}$ (basic) and $\mathrm{TiO}_{2}$ anatase powders with a molar ratio of 1:2. Uniaxially-pressed mixed powders were sintered at $1100^{\circ} \mathrm{C}$ in air for $2 \mathrm{~h}$ to obtain porous $\mathrm{MgTi}_{2} \mathrm{O}_{5}$ bars. Appropriate $\mathrm{Li}_{2} \mathrm{CO}_{3}$ and $\mathrm{SiO}_{2}$ doping ( 0.5 wt.\%) promoted uniform grain growth. However, with the excess amount of the impurities ( $>2$ wt.\%), the coefficient of thermal expansion of $\mathrm{Li}_{2} \mathrm{CO}_{3}$ - and $\mathrm{SiO}_{2}$-doped $\mathrm{MgTi}_{2} \mathrm{O}_{5}$ ceramics decreased obviously above $900^{\circ} \mathrm{C}$ and $950^{\circ} \mathrm{C}$ due to the secondary sintering. To keep the fine-grained porous microstructure of $\mathrm{Li}_{2} \mathrm{CO}_{3}{ }^{-}$and $\mathrm{SiO}_{2}$-doped samples with preventing the secondary sintering, impurity levels should be preferably limited less than $\sim 1.0$ wt.\%.
\end{abstract}

\section{Key-words:}

A. Powders: solid state reaction; A. Sintering; B. Impurities; C: Thermal expansion

\section{Introduction}

Diesel particulate filters (DPFs) are widely used for collecting particulate matter (PM) in the diesel exhaust gas [1-4]. Since it is necessary to regenerate the filter function by burning out the trapped PM in the DPF, high thermal-shock resistance is indispensable, which is realized by low thermal expansion as well as high mechanical strength, high thermal conductivity and low Young's modulus [1]. Cordierite $\left(2 \mathrm{MgO} \cdot 2 \mathrm{Al}_{2} \mathrm{O}_{3} \cdot 5 \mathrm{SiO}_{2}\right)$ and silicon carbide (SiC) have been

* Corresponding author (suzuki@ims.tsukuba.ac.jp)

Division of Materials Science, Faculty of Pure and Applied Sciences, University of Tsukuba, Ibaraki 305-8573, Japan 
widely used as wall-flow type DPF materials. Cordierite, a light-weight silicate-based compound, exhibits excellent low thermal expansion, so it is possible to integrally mold a large-sized honeycomb. It is superior in terms of the production cost due to low-cost natural resources and a reactive sintering process in air. The heat resistance of cordierite, however, is somewhat insufficient as compared with that of SiC. As for the SiC DPF, despite its excellent heat resistance and mechanical strength, its thermal expansion is much larger than that of cordierite, and hence additional steps of forming and bonding small segments with typical cross-sections of $\sim 3 \mathrm{~cm} \times 3 \mathrm{~cm}$ are required [4]. That is somewhat disadvantageous in terms of the production cost.

Both cordierite (the first generation) and SiC (the second generation) DPFs have excellent track records in the market, but still, nonsilicate-oxide-based DPFs (the third generation) enabling both low-cost and excellent heat resistance have been developed and are recently put into practical use $[5,6]$. Aluminum titanate $\left(\mathrm{Al}_{2} \mathrm{TiO}_{5}, \mathrm{AT}\right)$ having pseudobrookite-type structure is promising as a third-generation DPF material. The pseudobrookite-type crystal structure exhibits highly anisotropic thermal expansion [7], which induces the formation of intergranular and intragranular microcracks. These microcracks relax the thermal stress of particles, and hence, the pseudobrookite-type ceramics generally have low coefficient of bulk thermal expansion. A possible weak point of AT, however, is its instability at middle-range temperatures; $\mathrm{Al}_{2} \mathrm{TiO}_{5}$ is metastable below $1200{ }^{\circ} \mathrm{C}$ due to the large distortion of $\mathrm{MeO}_{6}$-octahedra, and thus undoped- $\mathrm{Al}_{2} \mathrm{TiO}_{5}$ tends to decompose into $\mathrm{Al}_{2} \mathrm{O}_{3}$ and $\mathrm{TiO}_{2}$. At the present time, US Corning [5] and Sumitomo Chemical Co. [8] have succeeded in the commercialization of AT-based DPFs with some oxide additives for improving the middle-range temperature stability. The AT-based DPF can be integrally molded and sintered in an air atmosphere, as with cordierite. Due to its high heat resistance, AT-based DPF shows high performance (secondarily to SiC DPF) at relatively low cost.

Since the thermal-expansion anisotropy of another pseudobrookite-type compound, $\mathrm{MgTi}_{2} \mathrm{O}_{5}\left(\mathrm{MT}_{2}\right)$, is not as prominent as $\mathrm{Al}_{2} \mathrm{TiO}_{5}, \mathrm{MgTi}_{2} \mathrm{O}_{5}$ is thermally more stable than $\mathrm{Al}_{2} \mathrm{TiO}_{5}$ [9-16]. Recently, Suzuki et al. [17-24] have focused on $\mathrm{MgTi}_{2} \mathrm{O}_{5}$ as potential materials for third generation DPFs, water purification filters and light-weight structural components. To realize the future applications of $\mathrm{MT}_{2}$-based components, influence of impurities (either in starting materials or during processing) on phase and microstructure stabilities of porous $\mathrm{MgTi}_{2} \mathrm{O}_{5}$ should be studied. Here, impurity effects on phase and microstructure stabilities of reactively-sintered porous $\mathrm{MgTi}_{2} \mathrm{O}_{5}$ have been studied. As model impurities, $\mathrm{Li}_{2} \mathrm{CO}_{3}$ (melting point: $723{ }^{\circ} \mathrm{C}$, decomposition temperature: $\sim 1300{ }^{\circ} \mathrm{C}$ ) and amorphous $\mathrm{SiO}_{2}$ (i.e. a typical impurity from natural resources) have been selected. 


\section{Experimental procedures}

The raw materials used to prepare porous $\mathrm{MgTi}_{2} \mathrm{O}_{5}$ ceramics were $\mathrm{MgCO}_{3}$ (basic) powder (99.9\% purity, $\mathrm{Mg}_{5}\left(\mathrm{CO}_{3}\right)_{4}(\mathrm{OH})_{2} \bullet 4 \mathrm{H}_{2} \mathrm{O}$, hydromagnesite) and $\mathrm{TiO}_{2}$ anatase powder $(99.9 \%$, Kojundo Chemical Laboratory Co. Ltd.) with a molar ratio of 1:2. As simulated impurities, $\mathrm{Li}_{2} \mathrm{CO}_{3}$ powder (99\%, Wako Pure Chemical) or $\mathrm{SiO}_{2}$ powder $(99.9 \%$, amorphous, Wako Pure Chemical) with a different amount (0.1 wt.\%, 0.5 wt.\%, 1.0 wt.\%, 2.0 wt.\%, or 4.0 wt.\%) was added to prepare the mixed powders. The powders were wet-ball milled with $\mathrm{ZrO}_{2}$ balls in ethanol for $24 \mathrm{~h}$. The mixed slurries were vacuum dried and placed into an oven at $80^{\circ} \mathrm{C}$ overnight. The dried powders were then sieved through a 150-mesh screen. The mixed powders were then uniaxially pressed into rectangular bars of $5 \times 6 \times 50 \mathrm{~mm}$ at the pressure of $18 \mathrm{MPa}$ for $1 \mathrm{~min}$. After pressing, the samples were sintered at $1100^{\circ} \mathrm{C}$ in air for $2 \mathrm{~h}$ to obtain porous $\mathrm{MgTi}_{2} \mathrm{O}_{5}$ bars. Phase analysis was performed with X-ray diffraction (XRD, Cu- $\mathrm{K}_{\alpha}, 40 \mathrm{kV}$ and $40 \mathrm{~mA}$, Multiflex, Rigaku, Japan). The density was determined by the dimensions and mass. The microstructure of porous $\mathrm{MgTi}_{2} \mathrm{O}_{5}$ ceramics was observed by scanning electron microscopy (SEM, JSM-5600LV, JEOL, Japan). The pore-size distributions and the pore volumes were determined by the mercury porosimetry (AutoPore IV 9520, Micromeritics).

Coefficient of thermal expansion (CTE) of the porous $\mathrm{MgTi}_{2} \mathrm{O}_{5}$ bars $(\sim 15-18 \mathrm{~mm})$ was determined by the thermal mechanical analysis (TMA, Thermal plus EVO, Rigaku, Japan). In order to evaluate the fracture strength, sintered rectangular bars were machined into the test specimens. The tensile face and corners of each specimen were polished and chamfered by waterproof abrasive paper. Fracture strength was measured by the three-point bending test with a span of $30 \mathrm{~mm}$ and a crosshead speed of $0.5 \mathrm{~mm} / \mathrm{min}$ by using a universal testing machine (Autograph AG-20kN, Shimadzu Co. Ltd., Japan). Three specimens were used for each measurement.

\section{Results and discussion}

\subsection{Phase analysis}

Figure 1 shows XRD patterns of porous $\mathrm{MgTi}_{2} \mathrm{O}_{5}$ with (a) $\mathrm{Li}_{2} \mathrm{CO}_{3}$ and (b) $\mathrm{SiO}_{2}$ impurities. As can be seen in Fig. 1 (a), without any impurity, $\mathrm{MgO}$ and $\mathrm{TiO}_{2}$ reacted to form single-phase $\mathrm{MgTi}_{2} \mathrm{O}_{5}$ by the reactive sintering at $1100{ }^{\circ} \mathrm{C}$. However, with $\mathrm{Li}_{2} \mathrm{CO}_{3}$ impurity, a small amount of $\mathrm{MgTiO}_{3}$ remained as an intermediate product. $\mathrm{MgTiO}_{3}$ peaks became stronger with increasing the amount of $\mathrm{Li}_{2} \mathrm{CO}_{3}$, similarly to the previous report with $\mathrm{LiF}$ doping [21]. To form the final $\mathrm{MgTi}_{2} \mathrm{O}_{5}$ phase, intermediate $\mathrm{MgTiO}_{3}$ particles should further reacts with $\mathrm{TiO}_{2}$ particles. In the interior of the porous body, however, some isolated $\mathrm{MgTiO}_{3}$ particles on the anisotropically-grown $\mathrm{MgTi}_{2} \mathrm{O}_{5}$ particles could not further react with $\mathrm{TiO}_{2}$. This hypothesis is well-supported by the mercury porosimetry in the latter part, which clearly demonstrated the 
enlargement of the pore size by the addition of $\mathrm{Li}_{2} \mathrm{CO}_{3}$. Note that the effective ionic radii of 6-coordinate $\mathrm{Li}^{+}$and $\mathrm{Mg}^{2+}$ are $0.76 \AA$ and $0.720 \AA$ [25], some $\mathrm{Li}^{+}$may dissolve in $\mathrm{MgTi}_{2} \mathrm{O}_{5}$ and $\mathrm{MgTiO}_{3}$ phases, without apparent changes of lattice parameters. Excess $\mathrm{TiO}_{2}$ then probably compensated the formation of $\mathrm{MgTi}_{2} \mathrm{O}_{5}$ (ss) and $\mathrm{MgTiO}_{3}$ (ss).

With $\mathrm{SiO}_{2}$ impurity (Fig. 1 (b)), $\mathrm{TiO}_{2}$ rutile peaks were confirmed for the samples with $\geq 0.5$ wt. $\% \mathrm{SiO}_{2}$, and $\mathrm{Mg}_{2} \mathrm{SiO}_{4}$ (forsterite) peaks were confirmed for those with $\geq 2.0 \mathrm{wt} . \% \mathrm{SiO}_{2}$. $\mathrm{TiO}_{2}$ rutile was formed by the phase transformation of unreacted $\mathrm{TiO}_{2}$ anatase, and $\mathrm{Mg}_{2} \mathrm{SiO}_{4}$ was yielded as a byproduct. Contrary to the $\mathrm{Li}_{2} \mathrm{CO}_{3}$ case, decrease of the pore size by the addition of $\mathrm{SiO}_{2}$ was observed (via the mercury porosimetry as shown in the latter part), which is in good agreement with the no intermediate $\mathrm{MgTiO}_{3}$ in the final product.

\subsection{Bulk density and apparent porosity}

Figure 2 shows the bulk density of porous $\mathrm{MgTi}_{2} \mathrm{O}_{5}$ with (a) $\mathrm{Li}_{2} \mathrm{CO}_{3}$ and (b) $\mathrm{SiO}_{2}$ impurities. Relative density values (insert) were nominally calculated from the theoretical density of $\mathrm{MgTi}_{2} \mathrm{O}_{5}, 3.644 \mathrm{~g} / \mathrm{cm}^{3}$, without taking into account second phases. Volume shrinkage with $\mathrm{Li}_{2} \mathrm{CO}_{3}$ impurity is also demonstrated (insert). It can be obviously seen from Fig. 2 (a) that the bulk density linearly increased with increasing the amount of $\mathrm{Li}_{2} \mathrm{CO}_{3}$. The result indicates that $\mathrm{Li}_{2} \mathrm{CO}_{3}$-doping may be an effective way to control the bulk density of porous $\mathrm{MgTi}_{2} \mathrm{O}_{5}$. With $\mathrm{SiO}_{2}$ impurity (Fig. 2 (b)), bulk density increased (up to $\sim 0.5$ wt.\%), and then decreased (with the amount of $\mathrm{SiO}_{2}$ ). The increase can be explained by the formation of glassy phase $\mathrm{SiO}_{2}$, and the decrease may be explained by the formation of second phases (as well as the intrinsic light-weight nature of $\mathrm{SiO}_{2}$ ).

\subsection{Microstructure}

Figure 3 shows the microstructure of (a) non-doped porous $\mathrm{MgTi}_{2} \mathrm{O}_{5}$, (b)-(f) porous $\mathrm{MgTi}_{2} \mathrm{O}_{5}$ with $\mathrm{Li}_{2} \mathrm{CO}_{3}$ and $(\mathrm{g})-(\mathrm{k})$ porous $\mathrm{MgTi}_{2} \mathrm{O}_{5}$ with $\mathrm{SiO}_{2}$. The non-doped porous $\mathrm{MgTi}_{2} \mathrm{O}_{5}$ sample presented a microstructure with small particle size and relatively narrow pore-size distribution (Fig. 3(a)). For the $\mathrm{Li}_{2} \mathrm{CO}_{3}$-doped samples, the grain size increased with increasing the amount of $\mathrm{Li}_{2} \mathrm{CO}_{3}$. Liquid phase formation during the reactive sintering caused the grain growth due to the low melting point of $\mathrm{Li}_{2} \mathrm{CO}_{3}\left(\sim 723^{\circ} \mathrm{C}\right.$, or even less due to the eutectic formation). For example, the sample with $2.0 \mathrm{wt} . \% \mathrm{Li}_{2} \mathrm{CO}_{3}$ presented a uniform microstructure with the typical grain size of $\sim 1-2 \mu \mathrm{m}$ (Fig. 3(e)). Excess $\mathrm{Li}_{2} \mathrm{CO}_{3}$ addition promoted inhomogeneous localized sintering and may form some closed pores (Fig. 3(f)), thereby reducing porosity of $\mathrm{MgTi}_{2} \mathrm{O}_{5}$ ceramics.

As can be seen in Fig. 3 (g), the sample with 0.1 wt. $\% \mathrm{SiO}_{2}$ contained relatively large flaw probably due to inhomogeneous dispersion of $\mathrm{SiO}_{2}$. The sample with 0.5 wt.\% $\mathrm{SiO}_{2}$ 
presented a uniform 3-D network microstructure (Fig. 3(h)), similarly to the reported porous $\mathrm{MgTi}_{2} \mathrm{O}_{5}$ with 0.5 wt.\% $\mathrm{LiF}$ additive [18]. Excess $\mathrm{SiO}_{2}$ addition $\left(\geq 1.0\right.$ wt.\% $\mathrm{SiO}_{2}$ ) promoted inhomogeneous localized sintering, similarly to Fig. 3(f), but suppressed grain growth. From the SEM observation for the $1100^{\circ} \mathrm{C}$-sintered samples, excess $\mathrm{Li}_{2} \mathrm{CO}_{3}$ (with low melting point) accelerated the grain growth by liquid phase formation, whereas excess amorphous $\mathrm{SiO}_{2}$ suppressed the grain growth and formed inhomogeneous microstructure.

Figure 4 and Table 2 show the pore-size distributions and the pore volumes measured by the mercury porosimetry. As can be seen in Fig. 4 and Table 2, although both $\mathrm{Li}_{2} \mathrm{CO}_{3}$ and $\mathrm{SiO}_{2}$ doping decreased the pore volume, the $\mathrm{Li}_{2} \mathrm{CO}_{3}$ doping increased the pore size, whereas the $\mathrm{SiO}_{2}$ doping decreased the pore size. These results are in good agreement with the SEM observation.

\subsection{The coefficient of thermal expansion}

Figure 5 presents the thermal expansion curves and the thermal expansion coefficients of $\mathrm{MgTi}_{2} \mathrm{O}_{5}$ with $\mathrm{Li}_{2} \mathrm{CO}_{3}$ and $\mathrm{SiO}_{2}$ impurities. For the samples with $\mathrm{Li}_{2} \mathrm{CO}_{3}$ (Figs. 5 (a) and (b)), there were little or no significant difference on thermal expansion between non-doped and $\leq 2$ wt. $\% \mathrm{Li}_{2} \mathrm{CO}_{3}$-doped $\mathrm{MgTi}_{2} \mathrm{O}_{5}$ samples up to $900^{\circ} \mathrm{C}$. The 4 wt. $\% \mathrm{Li}_{2} \mathrm{CO}_{3}$-doped $\mathrm{MgTi}_{2} \mathrm{O}_{5}$ showed higher thermal expansion, probably due to the increasing of intermediate $\mathrm{MgTiO}_{3}$ phases, as shown in Fig. 1(a). Decrease of the thermal expansion above $900^{\circ} \mathrm{C}$ for all the $\mathrm{Li}_{2} \mathrm{CO}_{3}$-doped $\mathrm{MgTi}_{2} \mathrm{O}_{5}$ samples can be attributed to the further densification (secondary sintering) during the TMA measurement. For the samples with $\mathrm{SiO}_{2}$ additives (Figs. 5 (c) and (d)), the thermal expansion and CTE curves were almost the same for all compositions. The bulk thermal expansion slightly decreased above $950^{\circ} \mathrm{C}$, which can be also attributed to the secondary sintering. Hence, the structural applications of fine-grained porous $\mathrm{MgTi}_{2} \mathrm{O}_{5}$ ceramics with $\mathrm{Li}_{2} \mathrm{CO}_{3}$-doping are preferably at less than $900^{\circ} \mathrm{C}$, and those with $\mathrm{SiO}_{2}$-doping are preferably less than $950^{\circ} \mathrm{C}$.

\subsection{Mechanical properties}

Figure 6 shows the 3-point bending fracture strength of porous $\mathrm{MgTi}_{2} \mathrm{O}_{5}$ with different impurities. Fracture strength of the sample with $\mathrm{Li}_{2} \mathrm{CO}_{3}$ impurity was almost constant up to 2.0 wt.\% addition, but their error bars became larger for the 1.0 and 2.0 samples. Fracture strength of the sample with $4.0 \mathrm{wt} . \% \mathrm{Li}_{2} \mathrm{CO}_{3}$ increased to $33.2 \mathrm{MPa}$ due to the progress of densification (see Figs. 2(a) and 3 (f)). Fracture strength of the sample with 0.1 wt. $\% \mathrm{SiO}_{2}$ addition showed slight drop probably due to the inhomogeneous microstructure (see Fig. 3 (g)). Fracture strength of the sample with 0.5 wt.\% $\mathrm{SiO}_{2}$ addition was much improved to $28.2 \mathrm{MPa}$ due to its homogeneous 3-D network structure. Fracture strength of the samples with $\geq 1.0$ wt.\% $\mathrm{SiO}_{2}$ became smaller once again, due to the inhomogeneity of the microstructure as well as the 
density drop (see Figs. 3 (i)-(k) and Fig. 2(b)).

\section{Conclusions}

We investigated the impurity effects on phase and microstructure stabilities of reactively-sintered porous $\mathrm{MgTi}_{2} \mathrm{O}_{5}$. Appropriate $\mathrm{Li}_{2} \mathrm{CO}_{3}$ and $\mathrm{SiO}_{2}$ doping promoted uniform grain growth with increased sintered density. However the coefficient of thermal expansion of $\mathrm{Li}_{2} \mathrm{CO}_{3}$ - and $\mathrm{SiO}_{2}$-doped $\mathrm{MgTi}_{2} \mathrm{O}_{5}$ ceramics decreased obviously above $900^{\circ} \mathrm{C}$ and $950^{\circ} \mathrm{C}$ due to the secondary sintering. To keep the fine-grained porous microstructure of $\mathrm{Li}_{2} \mathrm{CO}_{3}-$ and $\mathrm{SiO}_{2}$-doped samples with preventing the secondary sintering, impurity levels should be preferably limited less than $\sim 1.0 \mathrm{wt} . \%$.

\section{Acknowledgements}

A part of this work was supported by JSPS KAKENHI Grant Number JP16H04212 for Basic Research: Category B. We thank Dr. Kosuke Uoe and his colleagues at Sumitomo Chemical Co. Ltd. for kind measurements of the mercury porosimetry.

\section{References}

[1] J. Adler, Ceramic diesel particulate filters, Int. J. Appl. Ceram. Tech. 2 (2005) 429-439

[2] A. J. Pyzik, C. G. Li, New design of a ceramic filter for diesel emission control applications, Int. J. Appl. Ceram. Tech. 2 (2005) 440-451

[3] C. K. Narula, C. Stuart Daw, J. W. Hoard, T. Hammer, Materials issues related to catalysts for treatment of diesel exhaust, Int. J. Appl. Ceram. Tech. 2 (2005) 452-466

[4] K. Ohno, The $\mathrm{SiC}$ porous material technology which actualizes the development to diesel engine automobile business, (in Jpn.) Ceram. Jpn. 42 (2007) 431-438

[5] S. B. Ogunwumi, P. D. Tepesch, T. Chapman, C. J. Warren, I. M. Melscoet-Chauvel, D. L. Tennent, Aluminum titanate compositions for diesel particulate filters, SAE Technical Paper 2005-01-0583, 2005.

[6] I. J. Kim, Thermal stability of $\mathrm{Al}_{2} \mathrm{TiO}_{5}$ ceramics for new diesel particulate filter applications - a literature review, J. Ceram. Proc. Res. 10 (2009) 411-418

[7] G. Bayer, Thermal expansion characteristics and stability of pseudobrookite-type compounds, $\mathrm{Me}_{3} \mathrm{O}_{5}$, J. Less-Common. Metal. 24 (1971) 129-138

[8] A. Nemoto, K. Iwasaki, O. Yamanishi, K. Tsuchimoto, K. Uoe, T. Toma, H. Yoshino, Development of innovative diesel particulate filters based on aluminum titanate: design and validation, R\&D Report Sumitomo Kagaku, 2011-II (pp. 1-11)

[9] E.A. Bush, F.A. Hummel, High-temperature mechanical properties of ceramic materials. 1. Magnesium dititanate, J. Am. Ceram. Soc. 41 (1958) 189-195 
[10] J.A. Kuszyk, R.C. Bradt, Influence of grain-size on effects of thermal-expansion anisotropy in $\mathrm{MgTi}_{2} \mathrm{O}_{5}$, J. Am. Ceram. Soc. 56 (1973) 420-423

[11] J.J. Cleveland, R.C. Bradt, Grain size/microcracking relations for pseudobrookite oxides, J. Am. Ceram. Soc. 61 (1978) 478-481

[12] I. Shindo, Determination of the phase diagram by the slow cooling float zone method: the system $\mathrm{MgO}-\mathrm{TiO}_{2}$, J. Cryst. Growth 50 (1980) 839-851.

[13] J. Hauck, Crystallography and phase relations of $\mathrm{MeO}-\mathrm{M}_{2} \mathrm{O}_{3}-\mathrm{TiO}_{2}$ systems $(\mathrm{Me}=\mathrm{Fe}, \mathrm{Mg}$, $\mathrm{Ni}$; M=Al, Cr, Fe), J. Solid State Chem. 36 (1981) 52-65.

[14] B.A. Wechsler, A. Navrotsky, Thermodynamics and structural chemistry of compounds in the system $\mathrm{MgO}-\mathrm{TiO}_{2}$, J. Solid State Chem. 55 (1984) 165-180.

[15] D. Taylor, Thermal expansion data: XI. Complex oxides, $\mathrm{A}_{2} \mathrm{BO}_{5}$, and the garnets, $\mathrm{Br}$. Ceram. Trans. J. 86 (1987) 1-6

[16] B.A. Wechsler, R.B. von Dreele, Structure refinements of $\mathrm{Mg}_{2} \mathrm{TiO}_{4}, \mathrm{MgTiO}_{3}$ and $\mathrm{MgTi}_{2} \mathrm{O}_{5}$ by time-of-flight neutron powder diffraction, Acta Cryst. B 45 (1989) 542-549

[17] Y. Suzuki, M. Morimoto, Porous $\mathrm{MgTi}_{2} \mathrm{O}_{5} / \mathrm{MgTiO}_{3}$ composites with narrow pore-size distribution: in situ processing and pore structure analysis, J. Ceram. Soc. Jpn. 118 (2010) 819-822

[18] Y. Suzuki, M. Morimoto, Uniformly porous $\mathrm{MgTi}_{2} \mathrm{O}_{5}$ with narrow pore-size distribution: in situ processing, microstructure and thermal expansion behavior, J. Ceram. Soc. Jpn. 118 (2010) 1212-1216

[19] Y. Suzuki, Y. Shinoda, Magnesium dititanate $\left(\mathrm{MgTi}_{2} \mathrm{O}_{5}\right)$ with pseudobrookite structure: a review, Sci. Tech. Adv. Mater. 12 (2011) no.034301

[20] Y. Suzuki, T. S. Suzuki, Y. Shinoda, K. Yoshida, Uniformly porous $\mathrm{MgTi}_{2} \mathrm{O}_{5}$ with narrow pore-size distribution: XAFS study, improved in-situ synthesis, and new in-situ surface coating, Adv. Eng. Mater. 14 (2012) 1134-1138

[21] Y. Nakagoshi, Y. Suzuki, Pseudobrookite-type $\mathrm{MgTi}_{2} \mathrm{O}_{5}$ water-purification filter with controlled particle morphology, J. Asian Ceram. Soc. 3 (2015) 334-338

[22] Y. Nakagoshi, J. Sato, M. Morimoto, Y. Suzuki, Near-zero volume-shrinkage in reactive sintering of porous $\mathrm{MgTi}_{2} \mathrm{O}_{5}$ with pseudobrookite-type structure, Ceram. Int. 42 (2016) 9139-9144

[23] H.-W. Son, R. S. S. Maki, B.-N. Kim, Y. Suzuki, High-strength pseudobrookite-type $\mathrm{MgTi}_{2} \mathrm{O}_{5}$ by spark plasma sintering, J. Ceram. Soc. Jpn. 124 (2016) 838-840

[24] Y. Nakagoshi, Y. Suzuki, Dimensional change behavior of porous $\mathrm{MgTi}_{2} \mathrm{O}_{5}$ in reactive sintering, Ceram. Int. 43 (2017) 5541-5546

[25] R.D. Shannon, Revised effective ionic radii and systematic studies of interatomic distances in halides and chalcogenides, Acta Crystallogr. A 32 (1976) 751-757 


\section{Table}

Table 1 Content of raw materials and additives

\begin{tabular}{ccccc}
\hline Sample No. & $\mathrm{MgCO}_{3}$ (basic) $(\mathrm{g})$ & $\mathrm{TiO}_{2}$ (anatase) $(\mathrm{g})$ & $\mathrm{Li}_{2} \mathrm{CO}_{3}(\mathrm{~g})$ & $\mathrm{Li}_{2} \mathrm{CO}_{3}$ (wt.\%) \\
\hline $\mathrm{a}$ & 4.82 & 7.99 & 0 & 0 \\
$\mathrm{~b}$ & 4.82 & 7.99 & 0.013 & 0.1 \\
$\mathrm{c}$ & 4.82 & 7.99 & 0.064 & 0.5 \\
$\mathrm{~d}$ & 4.82 & 7.99 & 0.128 & 1.0 \\
e & 4.82 & 7.99 & 0.256 & 2.0 \\
f & 4.82 & 7.99 & 0.512 & 4.0 \\
\hline
\end{tabular}

\begin{tabular}{ccccc}
\hline Sample No. & $\mathrm{MgCO}_{3}($ basic $)(\mathrm{g})$ & $\mathrm{TiO}_{2}$ (anatase) $(\mathrm{g})$ & $\mathrm{SiO}_{2}(\mathrm{~g})$ & $\mathrm{SiO}_{2}(\mathrm{wt} . \%)$ \\
\hline $\mathrm{g}$ & 4.82 & 7.99 & 0.013 & 0.1 \\
$\mathrm{~h}$ & 4.82 & 7.99 & 0.064 & 0.5 \\
$\mathrm{i}$ & 4.82 & 7.99 & 0.128 & 1.0 \\
$\mathrm{j}$ & 4.82 & 7.99 & 0.256 & 2.0 \\
$\mathrm{k}$ & 4.82 & 7.99 & 0.512 & 4.0 \\
\hline
\end{tabular}

Table 2 Total pore volume measured by the mercury porosimetry.

\begin{tabular}{cc}
\hline \multicolumn{1}{c}{ Samples } & $\begin{array}{c}\text { Pore volume } \\
(\mathrm{mL} / \mathrm{g})\end{array}$ \\
\hline $\mathrm{a}$ (non doped) & 0.49 \\
$\mathrm{c}\left(\mathrm{Li}_{2} \mathrm{CO}_{3}-0.5\right)$ & 0.33 \\
$\mathrm{e}\left(\mathrm{Li}_{2} \mathrm{CO}_{3}-2.0\right)$ & 0.30 \\
$\mathrm{~h}\left(\mathrm{SiO}_{2}-0.5\right)$ & 0.42 \\
$\mathrm{j}\left(\mathrm{SiO}_{2}-2.0\right)$ & 0.26 \\
\hline
\end{tabular}




\section{Figure captions}

Fig. 1 XRD patterns of porous $\mathrm{MgTi}_{2} \mathrm{O}_{5}$ reactively sintered at $1100{ }^{\circ} \mathrm{C}$ with (a) $\mathrm{Li}_{2} \mathrm{CO}_{3}$ and (b) $\mathrm{SiO}_{2}$ impurities.

Fig. 2 Bulk density of porous $\mathrm{MgTi}_{2} \mathrm{O}_{5}$ with $\mathrm{Li}_{2} \mathrm{CO}_{3}$ and $\mathrm{SiO}_{2}$ impurities. Relative density values (insert) were nominally calculated from the theoretical density of $\mathrm{MgTi}_{2} \mathrm{O}_{5}$, $3.644 \mathrm{~g} / \mathrm{cm}^{3}$, without taking into account second phases. Volume shrinkage with $\mathrm{Li}_{2} \mathrm{CO}_{3}$ impurity is also demonstrated (insert): (a) non-doped porous $\mathrm{MgTi}_{2} \mathrm{O}_{5}$, (b)-(f) porous $\mathrm{MgTi}_{2} \mathrm{O}_{5}$ with $\mathrm{Li}_{2} \mathrm{CO}_{3}$ and (g)-(k) porous $\mathrm{MgTi}_{2} \mathrm{O}_{5}$ with $\mathrm{SiO}_{2}$.

Fig. 3 SEM micrographs of (a) non-doped porous $\mathrm{MgTi}_{2} \mathrm{O}_{5}$, (b)-(f) porous $\mathrm{MgTi}_{2} \mathrm{O}_{5}$ with $\mathrm{Li}_{2} \mathrm{CO}_{3}$ and $(\mathrm{g})-(\mathrm{k})$ porous $\mathrm{MgTi}_{2} \mathrm{O}_{5}$ with $\mathrm{SiO}_{2}$.

Fig. 4 Pore-size distributions determined by mercury porosimetry.

Fig. 5 Bulk thermal expansion of $\mathrm{MgTi}_{2} \mathrm{O}_{5}$ bars with various amount of $\mathrm{Li}_{2} \mathrm{CO}_{3}$ and $\mathrm{SiO}_{2}$ impurities sintered at $1100^{\circ} \mathrm{C}$ : (a,c) thermal expansion curves, and (b,d) linear thermal expansion.

Fig. 6 Fracture strength of porous $\mathrm{MgTi}_{2} \mathrm{O}_{5}$ with $\mathrm{Li}_{2} \mathrm{CO}_{3}$ and $\mathrm{SiO}_{2}$ impurities sintered at 1100 ${ }^{\circ} \mathrm{C}$. 
Figures
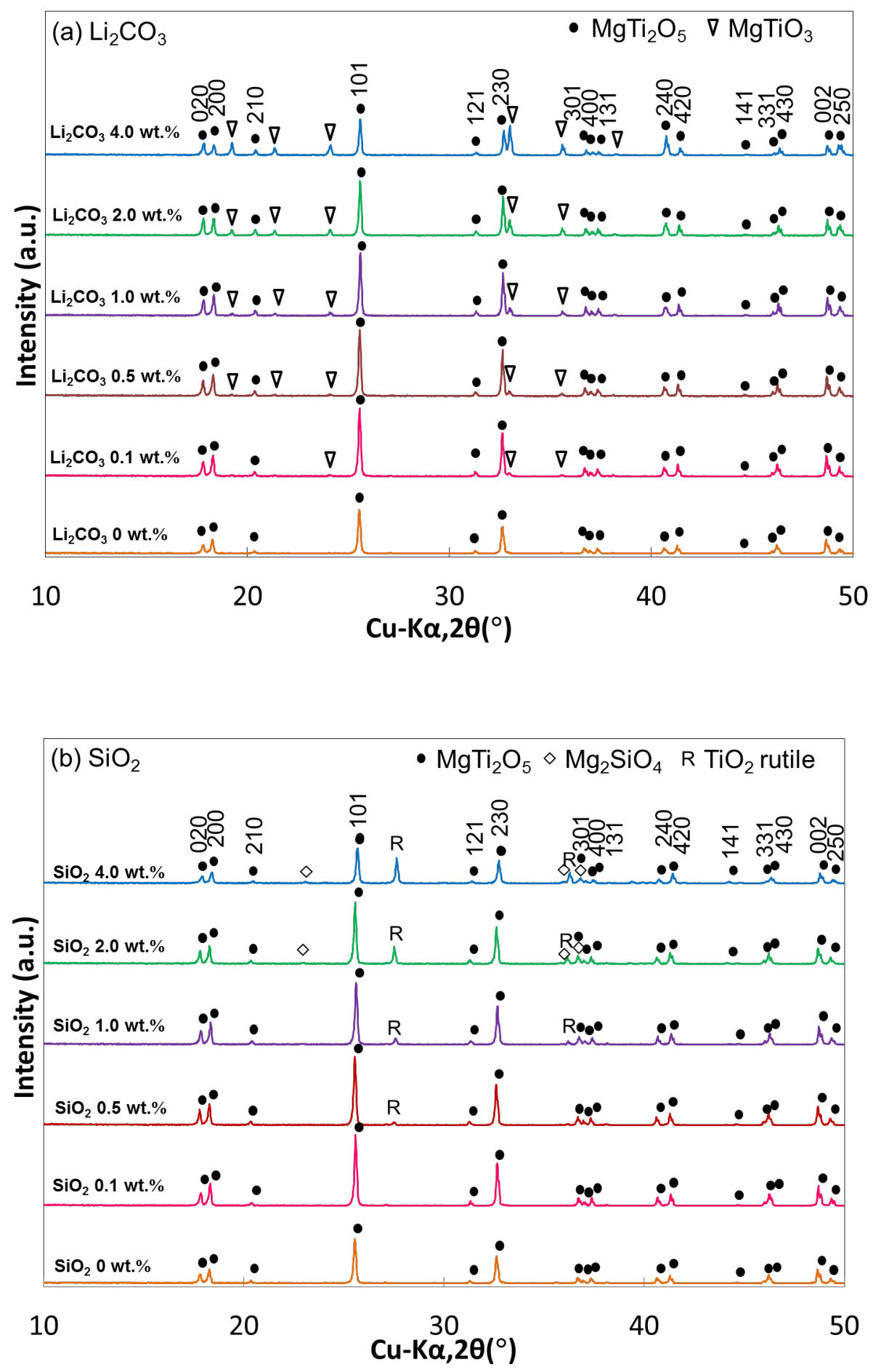

Fig. 1 XRD patterns of porous $\mathrm{MgTi}_{2} \mathrm{O}_{5}$ reactively sintered at $1100{ }^{\circ} \mathrm{C}$ with (a) $\mathrm{Li}_{2} \mathrm{CO}_{3}$ and (b) $\mathrm{SiO}_{2}$ impurities. 

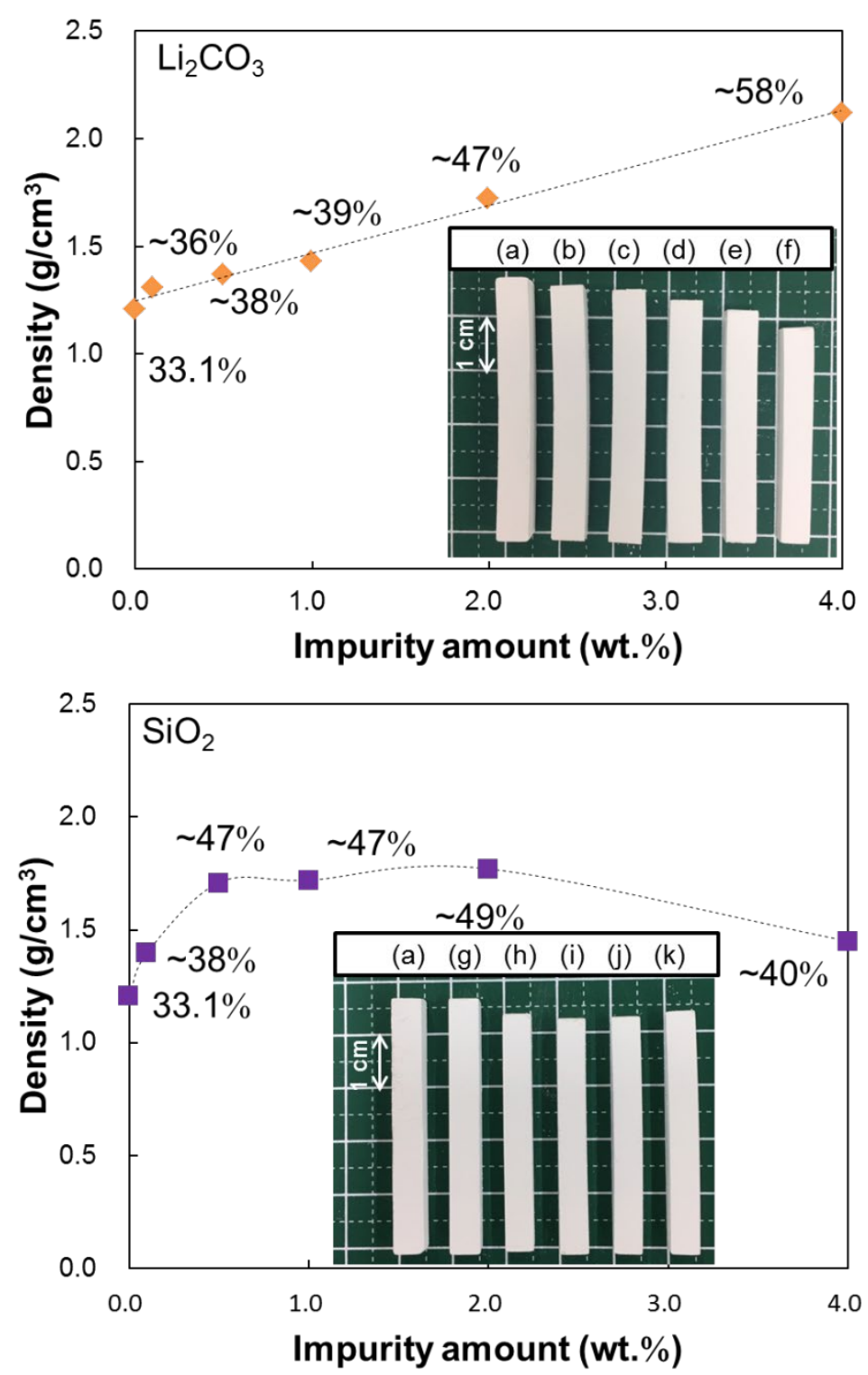

Fig. 2 Bulk density of porous $\mathrm{MgTi}_{2} \mathrm{O}_{5}$ with $\mathrm{Li}_{2} \mathrm{CO}_{3}$ and $\mathrm{SiO}_{2}$ impurities. Relative density values (insert) were nominally calculated from the theoretical density of $\mathrm{MgTi}_{2} \mathrm{O}_{5}, 3.644 \mathrm{~g} / \mathrm{cm}^{3}$, without taking into account second phases. Volume shrinkage with $\mathrm{Li}_{2} \mathrm{CO}_{3}$ impurity is also demonstrated (insert): (a) non-doped porous $\mathrm{MgTi}_{2} \mathrm{O}_{5}$, (b)-(f) porous $\mathrm{MgTi}_{2} \mathrm{O}_{5}$ with $\mathrm{Li}_{2} \mathrm{CO}_{3}$ and (g)-(k) porous $\mathrm{MgTi}_{2} \mathrm{O}_{5}$ with $\mathrm{SiO}_{2}$. 

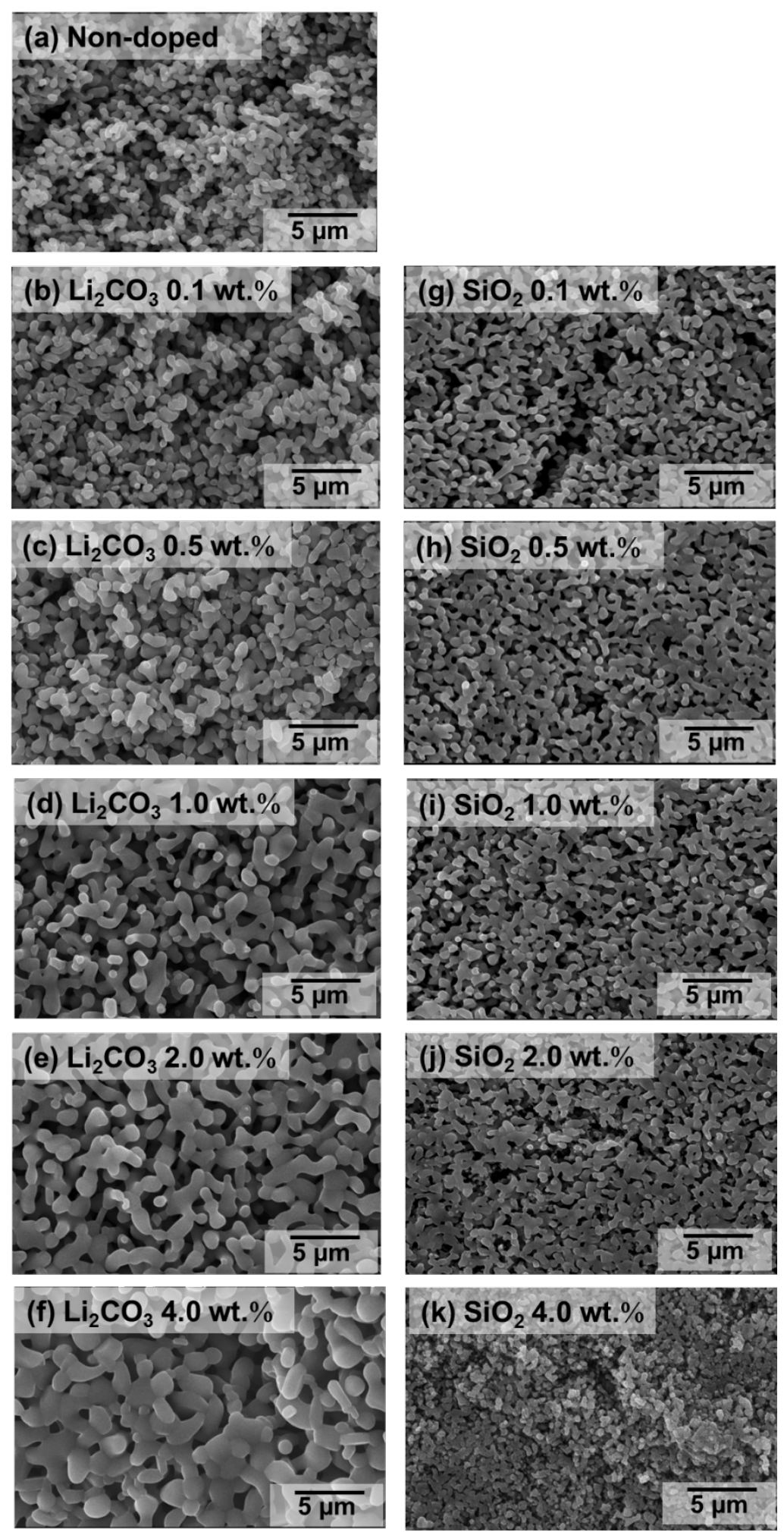

Fig. 3 SEM micrographs of (a) non-doped porous $\mathrm{MgTi}_{2} \mathrm{O}_{5}$, (b)-(f) porous $\mathrm{MgTi}_{2} \mathrm{O}_{5}$ with $\mathrm{Li}_{2} \mathrm{CO}_{3}$ and $(\mathrm{g})-(\mathrm{k})$ porous $\mathrm{MgTi}_{2} \mathrm{O}_{5}$ with $\mathrm{SiO}_{2}$. 


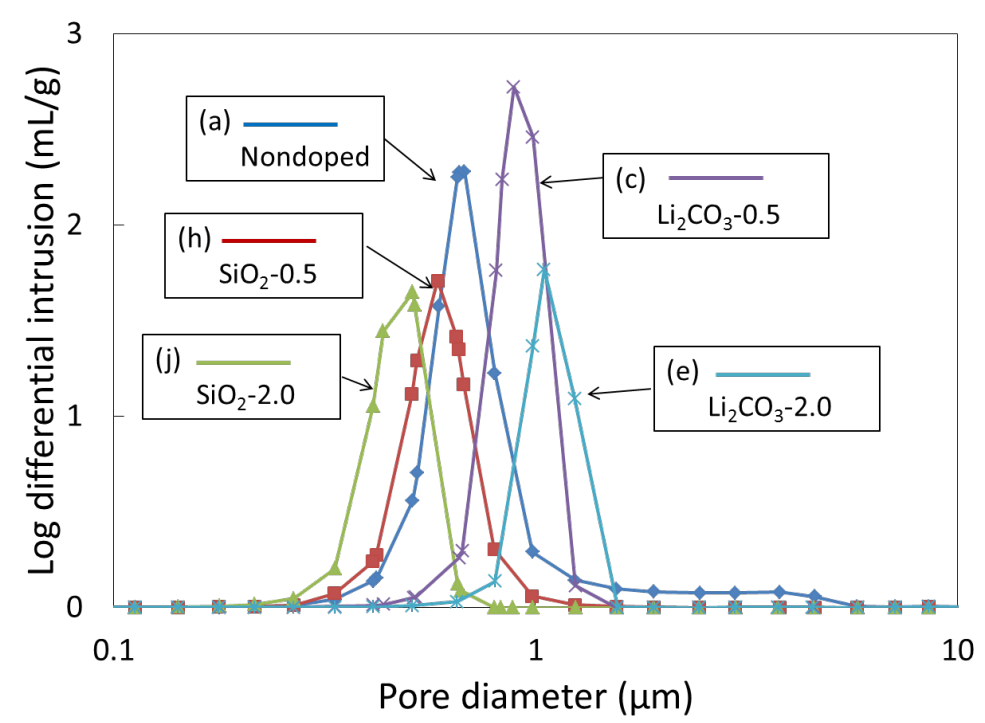

Fig. 4 Pore-size distributions determined by mercury porosimetry.
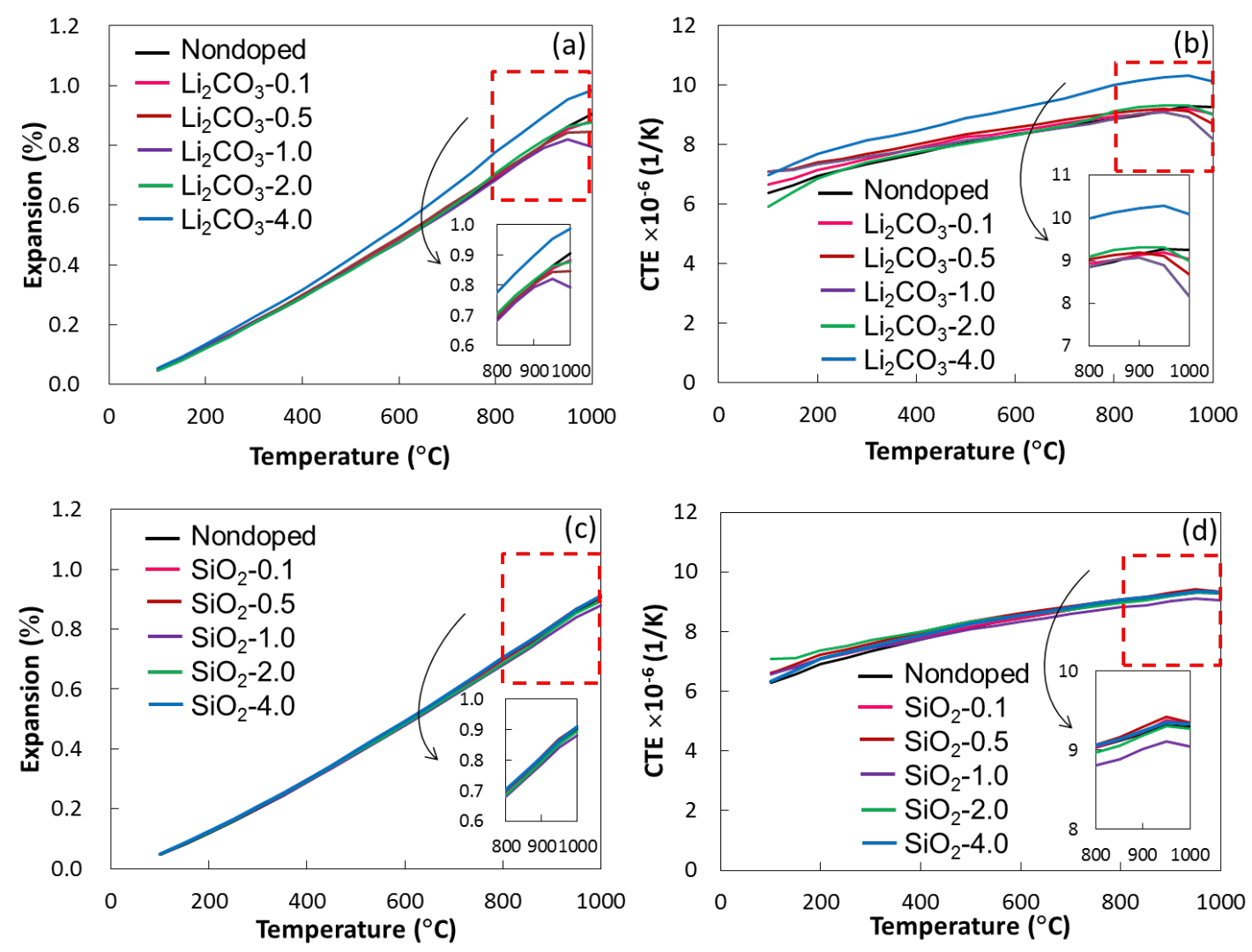

Fig. 5 Bulk thermal expansion of $\mathrm{MgTi}_{2} \mathrm{O}_{5}$ bars with various amount of $\mathrm{Li}_{2} \mathrm{CO}_{3}$ and $\mathrm{SiO}_{2}$ impurities sintered at $1100{ }^{\circ} \mathrm{C}$ : $(\mathrm{a}, \mathrm{c})$ thermal expansion curves, and $(\mathrm{b}, \mathrm{d})$ linear thermal expansion. 
Ceramics International

Short Communication

February 8, 2018 (revision)

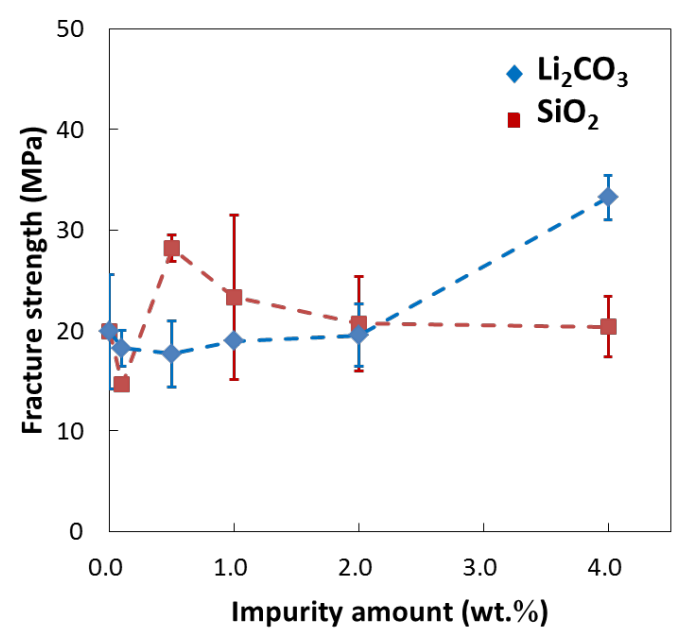

Fig. 6 Fracture strength of porous $\mathrm{MgTi}_{2} \mathrm{O}_{5}$ with $\mathrm{Li}_{2} \mathrm{CO}_{3}$ and $\mathrm{SiO}_{2}$ impurities sintered at 1100 ${ }^{\circ} \mathrm{C}$. 